\title{
Analysis on Practical Ability of English Major Students in Applied Colleges
}

\author{
Cui Li \\ Wuhan Donghu University, Wuhan Hubei, 430212, China
}

Keywords: Applied, Colleges, English major, Practical ability.

\begin{abstract}
The objective of talent training in applied universities is to cultivate students into applied talents who can serve the local economic and thus stimulate the development of local economy. However, some issues in the current talent cultivation of English major in Chinese applied universities and the negligence in the cultivation of students' practical ability go against to the promotion in the quality of teaching for English major in universities. On the basis of this, this paper proceeded with the issues in teaching for English major in applied universities and explored the modes of practical teaching as well as the reform measures for practical teaching in the hope of further improving English major students' practical ability and promoting them to obtain better development in their social life.
\end{abstract}

\section{Introduction}

The English major in applied colleges considers cultivating students' social practical ability as the most fundamental teaching objective, hopes to significantly strengthen students' social competitiveness and post adaptability by carrying out practical teaching activities, and also hope to guarantee better development in teaching for English major in China while promoting students' successful employment. However, even though the teaching mode has been optimized and adjusted properly under the action of new curriculum reform, there are still some issues in teaching for English major from an overall perspective under the influence of Chinese traditional educational thought for a long time and the exploration on creative teaching thinking is still in the preliminary development stage; therefore, there are still some issues to be solved. For this reason, it is obvious that the exploration on practical teaching for English major in applied colleges on the current social background is of realistic significance for pointing out the direction for the development of practical teaching for English major.

\section{Employment competitiveness of English talents in applied colleges}

At the present stage, with the further development of economic globalization, the increasing influence of economic globalization on the economic society in China has resulted in that the students majoring in traditional tool-type English cannot to meet the need of China's international economic development to some extent, so colleges must explore out a more scientific teaching mode in combination with the market requirements, help to cultivate students' knowledge application ability and cross-culture communication ability etc., guide students to gradually become comprehensive English talents with innovation ability and thus lay a solid foundation for students' successful employment in society ${ }^{[1]}$. On the basis of this, it is required to pay attention to the curriculum structure setting during the cultivation of English talents in applied colleges, which not only need to provide some basic courses to cultivate students' basic ability but also need to set reasonable courses for knowledge expansion to help students to significantly improve their own language ability through 
learning. Thus, the construction of English major course system in applied colleges should be closely based on students' employment competitiveness, professional ability and post adaptability etc., guarantee that the talent cultivation in teaching can adapt to students' need of career development, create conditions for students' successful employment and also provide corresponding talent guarantee for the development of local economy.

\section{Major issues in the curriculum setting and construction for English major in China's applied colleges at the present stage}

The positioning of applied universities in the field of social education is to serve the local economy, cultivate corresponding talents for local economic development and provide corresponding talent guarantee for economic construction. In order to obtain better development in the new era and promote to give full play to their functions in cultivating high-quality talents and promoting the development of local economy, the English major in applied colleges should provide related specialty based on the social talent need and the development positioning of students, continuously optimize and adjust their own mode of talent cultivation accordingly, and scientifically and reasonably provide teaching curriculum. Only in this way, can applied colleges cultivate English major students into high-quality comprehensive talents who can meet the society's talent need. At this stage, the English major of applied colleges in China has properly made reasonable reforms in the mode of talent cultivation based on the educational core, curriculum setting, advocates reforms from the perspective of social need and in the problems easily caught during students' employment process after graduation, and hopes to significantly improve the quality of talent cultivation. However, from the perspective of application effect of the mode of English talent cultivation in applied colleges currently, the still existing problems in the cultivation of practical ability of English major students in applied colleges go against the optimization and development of talent cultivation and also limit students' development in an all-around way.

At the present stage, there are some problems in the provision of practical curriculum setting for English major in applied colleges and they are shown in the following aspects: firstly, the curriculum setting pays no attention to the cultivation of students' core competence and fails to highlight the teaching characteristics of English major. This will not only result in students' capability failure the practical application of English but also exert adverse effects on students' further study; besides, this will also limit students' strengthening of social adaptability and go against students' successfully entering into the society for employment after graduation. Secondly, due to the inadequate practicalness, the curriculum setting fails to meet the need of cultivating students' comprehensive quality. Although the teaching management department for English major in applied colleges has been aware of the importance of practical talent cultivation and provided some practical teaching contents, the majority of domestic English teachers still focuses on theoretical teaching in their professional teaching activities and considers vocabulary recitation and exercise training as the major teaching contents and relatively neglects the cultivation of students' listening and speaking ability and cross-culture communication ability; for this reason, students' practical ability cannot be improved effectively. If this continues for a long time, it will certainly restrict students' growth and have adverse effects on the enhancement of students' employment ability. Thirdly, students' professional practical ability needs to be improved. With the continuous reform in teaching mode and increasing perfection of educational system in the new era, to guarantee realize the fundamental objective of talent cultivation by carrying out their curriculum teaching activities, college teachers have also strengthened the exploration in pluralistic teaching concepts and teaching modes, gradually considered students as the center of all teaching activities and cultivated students' practical ability. However, from an overall perspective, the inadequate pertinence in teachers' teaching activities and the lack of favorable communications between teachers and students have leaded to the unsatisfactory teaching effect, so students' practical ability still needs to be further improved. Fourthly, the selection of teaching materials lacks rationality. Due to the low speed in updating of versions of teaching materials at the present stage, the failure to scientifically adjust the contents in teaching materials 
based on changes in the need of era development and talent need in the market results in the lack of consistency between traditional teaching and English practical teaching in the new era, also affects the implementation of practical educational activities, goes against the cultivation of students' English practical ability and exerts some adverse effects on students' future development. Therefore, in order to truly and comprehensively promote the deep development of teaching reform in the new era, it is also required to explore more scientific teaching concepts and methods and offer high-quality educational guidance service. Only in this way, can we comprehensively enhance students' knowledge application ability, practical ability, innovation ability and communicative competence etc., help students to enhance their comprehensive quality and lay a foundation for students' future working life.

\section{Teaching rectification measures for cultivation of practical ability of English talents in applied colleges}

In consideration of the problems regarding the cultivation of practical ability of English talents in applied colleges, in order to improve the current teaching status, enhance the quality of practical teaching, provide corresponding guarantee for the exertion of function of practical teaching and practically cultivate students' practical ability, the English major of applied college should rectify and reform the current teaching mode, explore a more scientific mode of talent cultivation in combination with the society's talent need, the need of growth and development of students and students' learning ability etc., help to comprehensively strengthen students' English practical application ability, provide guarantee for students' successful employment in the future and lay a talent foundation for the construction and development of local economy.

\section{Actively change the traditional concept of curriculum setting for English major}

In China's traditional teaching for English major in colleges, under the influence of the thought of exam-oriented education, the teaching concept has increasingly deviated from the track of cultivating practical English talents for the society and meeting the society's need for talents. Besides, this improper transformation in teaching concept is most obvious in applied colleges. In view of this problem, the English major of applied colleges in all regions should adjust the curriculum structure based on more scientific curriculum concepts so that the curriculum setting can more accord with the development idea of English practical teaching and can cultivate students' practical ability. Firstly, it is required to break through the traditional rigid pattern with teachers as the subject in curriculum setting, strengthen the emphasis on students during the teaching process, highlight students' status of subject specified, let students to actively participate in teaching practice, help students to communicate with teachers and other students in English, help to well cultivate students' language ability and create conditions for the formation of students' cross-culture communication ability ${ }^{[2]}$. Secondly, it is required to explore diversified teaching methods in the process of curriculum setting, such as inquiry teaching method, task-based teaching method, case teaching method, scene-setting teaching method and group cooperative learning method, create some opportunities for English practice of students and cultivate students' English practical ability. Finally, as for curriculum setting, it is also required to fully analyze the current society's need for English talents, properly provide the simultaneous interpretation course, reporting ability guidance course and practical writing translation course etc. based on the social need, strive to help students to continuously enhance their all qualities in combination with their learning ability, realize the cultivation of students' comprehensive ability and point out the direction for students' future graduation development.

\section{Reasonably optimize the curriculum structure}

It was found through relevant investigations that the credits of required courses for English major in the majority of colleges of China still accounted for over $70 \%$ of the total assessment credits at this stage. Such curriculum structure setting will certainly result in that students invest many of their efforts in learning required specialized courses. As a result, students may have their theoretical 
English knowledge strengthened and their research ability in academic English gradually improved, but their interest in English learning will decrease gradually and adverse effects will caused on the cultivation of students' practical ability ${ }^{[3]}$. Therefore, to improve this situation, it is also required to reasonably optimize the curriculum structure during teaching for English major in applied colleges, properly adjust the proportion of required courses and add the specified proportion of elective courses so that students can choose some characteristics courses as their elective courses based on their future development direction and learning ability; besides, based on enhancing students' learning interest, teachers can also cultivate students' practical ability so as to lay a solid foundation for students' future development.

\section{Gradually enhance the proportion of practical teaching course in the overall curriculum}

Paying more attention to practical teaching in teaching for English major in applied colleges does not mean the proposition of completely replacing practical teaching with theoretical teaching but means the organic combination between theoretical teaching and practical teaching so that both of their functions can be fully exerted. Only in this way, can students form more deep understanding of English knowledge; in addition, conditions can be created for the cultivation of students' comprehensive ability and students' practical ability can be strengthened well. For instance, when organizing students to learn a translation course, a teacher can break through the tradition, explore the task-driven teaching method, help students to enhance their practical ability accordingly by arranging some practical learning tasks, guide students to discuss and analyze the practical result after practical learning, permeate theoretical English knowledge when guiding students to discuss and analyze English knowledge and thus create conditions for cultivation of students' comprehensive ability ${ }^{[4]}$. Therefore, the proportion of practical courses for English major will increase gradually and students can accept more professional practical education.

\section{Properly provide courses to train teachers' practical ability}

In the teaching for English major in applied colleges, teachers are the executors to provide practical courses and cultivate students' practical ability, so teachers' practical teaching ability and their ability to apply English knowledge should also exert specific influences on the cultivation of students' practical ability. According to this, college English teachers should provide training courses to practically cultivate students' practical ability based on the current construction of teaching staff in their colleges and the deficiencies in their practical teaching so that teachers can give more scientific educational guidance for students with a better state, help students to strengthen their knowledge application ability, problem-solving ability and cross-culture communication ability etc., and provide students with corresponding guarantee for their working life ${ }^{[5]}$. As for concrete operations, colleges should give play to the function of "elder teachers guiding the younger ones" in the teaching concept so that elder teachers can lead and guide new ones and impart corresponding experience to new teachers; besides, teachers' practical education ability can be gradually strengthened. Meanwhile, as for the exploration of teaching methods, new teachers should also help the elder ones to update their traditional teaching concept and methods so that they can help to gradually enhance the teaching quality in their colleges through mutual assistance and then lay a solid foundation for the optimization and development of teaching activities.

\section{Conclusion}

To sum up, as the practical teaching for English major in applied colleges is currently at the development stage, various problems in practical teaching will exert adverse effects on the cultivation of students' practical ability. Therefore, based on improving their own practical teaching quality, teachers for English major in applied colleges should also update their teaching concept and methods, explore out more scientific teaching modes, provide students with high-quality educational guidance service, practically improve the current status of teaching for English major in applied colleges in our 
country, cultivate students into high-quality talents and thus make some contributions to the construction of society.

\section{Acknowledgement}

Fund project: approved project of teaching reform in Wuhan Donghu Lake of Wuhan in 2016: exploration and practice in practical teaching system for English major in applied colleges (project number: 161503)

\section{References}

[1] Zhou Yan. Exploration on approaches to cultivate the practical ability of English major students in colleges, Industrial \& Science Tribune, 2013, 12 (6):165-166.

[2] Li Manman and Ma Hongmei. Research on the action of cultivating the innovative ability of English major students in application-oriented universities, Journal of Chongqing University of Education, 2013, 26 (2):144-147, 151.

[3] Wang Guohua. Reform in basic course teaching for English major and cultivation of students' practical ability, Teaching of Forestry Region, 2013 (4): 38-39.

[4] Zhong Lei and Wang Long. Research on countermeasures for talent cultivation to meet enterprises' need and enhance employment ability in colleges - taking the cultivation of application-oriented English talents for example, Work \& Study Abroad, 2011 (11):10-12.

[5] Zhang Guoyan, Ma Chen and Zhao Xuewei et al. Importance of "sign language” in "translation” - investigation and research on the education and cultivation of "sign language to promote employment practical ability” for English major students in colleges, Intelligence, 2011 (5): 288. 